\title{
Influence of Extraction Parameters on Hydroalcohol Extracts of the Stem Bark of Rapanea ferruginea Mez Using Myrsinoic Acid B as Marker
}

\author{
Thaisa Baccarin ${ }^{1}$, Rene A Ferreira ${ }^{1}$, Vanessa F Gazoni ${ }^{1}$, Rosendo A Yunes ${ }^{2}$, \\ Ângela Malheiros ${ }^{1}$ and Ruth $M$ Lucinda-Silva ${ }^{1 *}$ \\ ${ }^{1}$ Núcleo de Investigação Químico-Farmacêutica (NIQFAR), Programa de Mestrado em Ciências Farmacêuticas, Universidade \\ do Vale do Itajaí, Itajaí-SC, ${ }^{2}$ Departamento de Química, Universidade Federal de Santa Catarina, Florianópolis-SC, Brazil \\ *For correspondence: Email: rlucinda@univali.br; Tel: +55 47 3341-7664; Fax: +55 47 3341-7744
}

\begin{abstract}
Purpose: To evaluate the influence of extraction parameters on standardization of hydroalcoholic extract of Rapanea ferruginea Mez.

Methods: $A 3^{3}$ factorial design was used to evaluate the influence of alcohol concentration (50, 70 and $90 \% \mathrm{v} / \mathrm{v})$, extraction time (2, 6 and $10 \mathrm{~h})$, and particle size of the herbal drug $(0.25,0.5$ and $1.0 \mathrm{~mm})$ on the $\mathrm{pH}$, dry residue and myrsinoic acid $B(M A B)$ content of hydroalcoholic extracts by high performance liquid chromatography (HPLC) method.

Results: For the extracts, there was inverse correlation between dry residue and MAB content ( $p<$ $0.8046)$. The parameter that had the greatest influence on extraction process was alcohol concentration $(p<0.007)$ followed by particle size $(p<0.046)$. However, extraction time did not influence the process in terms of MAB $(p<0.675)$. Although, the highest MAB content was obtained with $70 \% \mathrm{v} / \mathrm{v}$ alcohol and extraction time of $6 \mathrm{~h}$, the best methodology for extractive preparation was the use of $90 \% \mathrm{v} / \mathrm{v}$ alcohol and extraction time of $2 \mathrm{~h}$ because it resulted in a higher yield of MAB per solution volume, i.e,, with regard to $M A B$ content and mass yield.

Conclusion: The results indicate that $90 \% \mathrm{~V} / \mathrm{v}$ alcohol and extraction time of $2 \mathrm{~h}$ have optimum influence on extraction process and were the best conditions for obtaining a standardized extract of $R$. ferruginea, using the method employed in this study. Thus, the findings of this study are a contribution to the development of a new phytopharmaceutical intermediate product.
\end{abstract}

Keywords: Rapanea ferruginea, Hydroalcoholic extract, Myrsinoic acid B, Phytopharmaceutical, Factorial desing, Standardization

\footnotetext{
Tropical Journal of Pharmaceutical Research is indexed by Science Citation Index (SciSearch), Scopus, International Pharmaceutical Abstract, Chemical Abstracts, Embase, Index Copernicus, EBSCO, African Index Medicus, JournalSeek, Journal Citation Reports/Science Edition, Directory of Open Access Journals (DOAJ), African Journal Online, Bioline International, Open-J-Gate and Pharmacy Abstracts
}

\section{INTRODUCTION}

Plants are a source of conventional drugs, and the use of plant products in so-called complementary or alternative medicine has expanded in recent decades [1]. For the production of herbal medicines, development studies must first be conducted, following all the rules and processing steps [2]. As part of this process, the standardization of extract production methods is an essential step, since the fact that plants are subjected to variations in chemical composition can alter the content of active ingredients, or cause new substances to appear, due to the numerous variables to which they are exposed during their growth and in the process of harvest, drying, storage and extraction [3]. 
Rapanea synonym Myrsine (Myrsinaceae) is a pantropical genus and its distribution extends to Bolivia, Mexico, Argentina, Paraguay and Uruguay [4]. Rapanea ferruginea Mez. (Myrsine coriacea) is a tree that grows 6 to 12 meters in height; the trunk is 30 to $40 \mathrm{~cm}$ in diameter, and the leaves are leathery, measuring 7 to $9 \mathrm{~cm}$ length by 2 to $2.5 \mathrm{~cm}$ in width [5]. It is popularly known as capororoca, azeitona-do-mato, and pororoca. In traditional medicine has been reported the use of tea from leaves or stem bark of Myrsine parvifolia to diseases of the urinary tract, itching, rashes, hives, eczema, rheumatism and liver diseases [5].

The extracts of fruits and stem barks of $R$. ferruginea showed antioxidant activity similar to the positive control Trolox ${ }^{\circledR}$ with reduction of over $80 \%$ by DPPH and ORAC antioxidant models [6]. Diprenylated benzoic acid derivatives were the main compounds isolated from this genus, including the myrsinoic acids (MA) A, B, C, and $F$ [7].

Myrsinoic Acid B (MAB) showed a significant antinociceptive effect by interacting with the $\alpha$ adrenergic, cholinergic, and oxidonitrergic systems, with the HPA (hypothalamic-pituitaryadrenal), and partially, with the serotonergic system [8]. MAB reduced mechanical and thermal hypersensitivity in mice submitted to models of inflammatory and neuropathic pain, showing excellent potential for treating persistent pain in humans [9].

Although some studies with this species have been described in the literature, there is a lack of studies related to the physical, chemical and technological properties of extracts of $R$. ferruginea for obtaining an herbal medicine. This work reports on the development and optimization of hydroalcoholic extract of stem barks of $R$. ferruginea using factorial design. Extracts were standardized as to content of $M A B$, which is used as marker as it is the major compound, and due to its biological activity.

\section{EXPERIMENTAL}

\section{Plant material}

Stem bark of Rapanea ferruginea (Ruiz \& Pav.) Mez collected June 18, 2008 in Blumenau, Santa Catarina, Brazil, was used to produce the herbal drug. The stem bark was removed using chisel, ranging 20 and $60 \%$ of the diameter and 30 to $100 \mathrm{~cm}$ in length, according to ethnomedical studies carried out previously (unpublished data).
Botanical authenticity was carried out by comparison between the plant voucher specimen collected by Rene Artur Ferreira (Univali, Itajaí, Brazil) and the sample deposited at the Barbosa Rodrigues Herbarium (Itajaí-SC) with voucher number HBR 52715.

The material was dried in an oven with circulating air (Marconi®, São Paulo, Brazil) at temperature of $35 \pm 2{ }^{\circ} \mathrm{C}$ for 7 days. It was then ground in a hammer mill (Primotecnica $\AA$, São Paulo, Brazil), with a $2 \mathrm{~mm}$ mesh, thus providing the raw material.

\section{Characterization of herbal raw material}

The dried and powdered raw plant material was analyzed for particle size distribution by the sieving method (60 vibrations / $\mathrm{min}$ for $15 \mathrm{~min}$ ) with mesh openings of $0.25,0.5,1.0$ and 2.0 $\mathrm{mm}$, and the average particle size was calculated [10].

Determination of loss on drying was performed on an infrared balance (Mettler Toledo ${ }^{\circledR}$ LJ16 Moisture Analyzer, Columbus, USA). Samples of about $1.0 \mathrm{~g}$ of raw material were analyzed (triplicate) at $105^{\circ} \mathrm{C}$ until weight stabilization was obtained.

Determination of total ash and of acid-insoluble ash content were performed conform Brazilian Pharmacopoeia [11]. Samples of approximately $3.0 \mathrm{~g}$ of raw material were used. The results were expressed as ash percentage $(\% \mathrm{w} / \mathrm{w})$ by the average of three determinations.

\section{Optimization of extraction method}

The extraction solutions from the stem bark of $R$. ferruginea were obtained by dynamic maceration method with hydroethanolic solvent, at room temperature under stirring in a mechanical stirrer (Fisatom ${ }^{\circledR}$ 713D, São Paulo, Brazil) $(300 \pm 30$ rpm), without renewing the extractor liquid. The plant:solvent proportion was $10 \% \quad(\mathrm{w} / \mathrm{v})$. Subsequently, the extracts were filtered by vacuum filtration and stored in amber glass bottles.

To optimize the extraction process, a factorial design $3^{3}$ was used (Table 1 ). Three factors were tested at three levels, resulting in 27 batches of extraction solutions. The experiments were arranged randomly and without replacement. The independent factors analyzed were alcoholic degree (50, 70 and $90 \% \mathrm{v} / \mathrm{v})$, particle size of the herbal drug $(0.25,0.5$ and $1.0 \mathrm{~mm})$ and extraction time (2, 6 and $10 \mathrm{~h})$. The dependent factors analyzed were $\mathrm{pH}$, dry 
Table 1: Extractive batch nnumbers with the respective factors and levels studied in the factorial design

\begin{tabular}{|c|c|c|c|c|}
\hline \multirow[b]{2}{*}{ Factor B } & \multirow[b]{2}{*}{ Factor C } & \multicolumn{3}{|c|}{ Factor A } \\
\hline & & -1 & 0 & 1 \\
\hline-1 & -1 & $-1-1-1$ (batch 01) & $0-1-1$ (batch 10) & $+1-1-1($ batch 19) \\
\hline-1 & 0 & $-1-1-0$ (batch 02) & $0-1-0$ (batch 11) & $+1-1-0$ (batch 20) \\
\hline-1 & +1 & $-1-1+1$ (batch 03) & $0-1+1$ (batch 12) & $+1-1+1($ batch 21$)$ \\
\hline 0 & -1 & $-1-0-1$ (batch 04) & 0-0-1 (batch 13) & $+1-0-1$ (batch 22) \\
\hline 0 & 0 & $-1-0-0$ (batch 05) & $0-0-0$ (batch 14) & $+1-0-0$ (batch 23) \\
\hline 0 & +1 & $-1-0+1$ (batch 06) & $0-0+1$ (batch 15) & $+1-0+1$ (batch 24$)$ \\
\hline+1 & -1 & $-1+1-1$ (batch 07) & $0+1-1$ (batch 16) & $+1+1-1$ (batch 25) \\
\hline+1 & 0 & $-1+1-0$ (batch 08) & $0+1-0$ (batch 17) & $+1+1-0($ batch 26$)$ \\
\hline+1 & +1 & $-1+1+1$ (batch 09) & $0+1+1$ (batch 18) & $+1+1+1$ (batch 27$)$ \\
\hline
\end{tabular}

$A=$ alcohol concentration; $B=$ extraction time; $C=$ particle size

residue, and qualitative and quantitative analysis by HPLC using MAB as marker.

The results were analyzed using multiple regression analysis and response surface analysis was obtained from the fitted regression equations, using the Statistica ${ }^{\circledR} 6.0$ software $(p<$ 0.05).

The response function applied was a quadratic polynomial equation (equation 1), where $Y$ is the predicted response (dependent variable), $\beta_{0}$ is the average response, $\beta_{1}, \beta_{2}, \beta_{3}$ is the estimated coefficient for the $x_{1}, x_{2}$ and $x_{3}$ factors (1alcoholic degree; 2- time of extraction; 3- particle size), respectively, where $x_{1}, x_{2}$ and $x_{3}$ represent the independent variables; $\beta_{11}, \beta_{22}$ and $\beta_{33}$ correspond to cross product coefficients of $\mathrm{x}_{1} \mathrm{x}_{2}$, $x_{1} x_{3}$ and $x_{2} x_{3} ; \beta_{12}, \beta_{13}$ and $\beta_{23}$ correspond to the quadratic terms $\left(\mathrm{x}_{1}{ }^{2}, \mathrm{x}_{2}{ }^{2}\right.$ and $\left.\mathrm{x}_{3}{ }^{2}\right)$ that represent the response of the nonlinear analysis of the changes in factors.

$Y=\beta_{0}+\beta_{1} x_{1}+\beta_{2} x_{2}+\beta_{3} x_{3}+\beta_{11} x_{1}{ }^{2}+\beta_{22} x_{2}{ }^{2}+$ $\beta_{33} x_{3}{ }^{2}+\beta_{12} x_{1} x_{2}+\beta_{13} x_{1} x_{3}+\beta_{23} x_{2} x_{3} \ldots \ldots \ldots \ldots$ (1)

\section{Characterization of the standardized extracts}

The extract yield was determined as the difference of the volume of extract obtained after the extraction and the theoretical volume value. For determination of dry residue of the extraction solutions an aliquot of $10.0 \mathrm{~g}$ of extraction solution was exactly weighed in flat-bottomed dish previously weighted and evaporated to dryness in water-bath, occasionally stirring. After evaporation of the solvent, the set was taken to the oven $105 \pm 2{ }^{\circ} \mathrm{C}$ (Quimis $\circledR$, São Paulo, Brazil) until constant weight was obtained. The result was calculated for $100 \mathrm{~g}$ of extraction solution and expressed as mean and standard deviation of three determinations [11].

The $\mathrm{pH}$ of the extraction solutions was measured at $25{ }^{\circ} \mathrm{C}$, using $\mathrm{pH}$ meter calibrated (Digimed ${ }^{\circledR}$,
São Paulo, Brazil) with buffer solutions of phosphate and acetate, $\mathrm{pH} 7$ and 4, respectively [11].

\section{Analysis of extracts by HPLC}

Qualitative analyses of the chemical profile of the extracts and marker (MAB) were performed by HPLC-Photodiode Array (PDA) detector, using the validated isocratic elution method [7].

A Shimadzu LC-10AD LC system (Shimadzu, Tokyo, Japan), consisting of a binary pump and a Shimadzu SPD-M10A photo diode array detector, SIL-10A auto-sampler and software Class VP (version 5.33), was used. The injections $(20 \mu L)$ were carried out on a Phenomenex (Torrance, California, USA) Luna C18 $5 \mu \mathrm{m}$ Fusion RP $100 \AA$ (250 × $4.6 \mathrm{~mm})$ conditioned in a Shimadzu CTO-10A column oven equilibrated at $35^{\circ} \mathrm{C}$. The mobile phase consisted of a mixture of acetonitrile-methanolwater ( $\mathrm{pH} 2.6$, phosphoric acid) (48:30:22, v/v/v), at a flow rate of $0.7 \mathrm{ml} / \mathrm{min}$.

Hydroalcoholic extract was diluted at 1:10 in mobile phase and filtered through a $0.45 \mu \mathrm{m}$ cellulose regenerated membrane filter. For preparation of $100 \mu \mathrm{g} / \mathrm{ml}$ standard solution, AMB (1 $\mathrm{mg}$ ) was dissolved in $10 \mathrm{~mL}$ of mobile phase by sonication for $5 \mathrm{~min}$ to prepare a fresh working solution. The content of MAB was calculated as $\mathrm{mg} / \mathrm{g}$ of $\mathrm{MAB}$ in dry residue of extraction solution, applying $M A B$ as external standard.

\section{Statistical analysis}

The data were expressed as mean \pm standard deviation (SD) and statistical analysis was carried out by one-way ANOVA using experimental design tools of Statistica ${ }^{\circledR} 6.0$ software followed by Tukey test. The level of significance used was $p<0.05$. 


\section{RESULTS}

\section{Characterization of raw material}

In the present work, only stem bark from trees with a trunk circumference of 20 to $25 \mathrm{~cm}$ was used, to ensure homogeneity of size tree. An average yield of $46.69 \%(\mathrm{w} / \mathrm{w})$ of dry stem bark was obtained after drying.

The milled herbal drug used has wide particle size distribution, with a greater yield of particles in the fraction between 1.0 to $2.0 \mathrm{~mm}$ and 0.5 to $1.0 \mathrm{~mm}, 36.9 \%$ and $32.5 \%$ respectively. The wide particle size distribution is probably related to the hardness of the herbal drug, and hence, the difficulty of pulverizing it. The average particle size was $0.87 \mathrm{~mm}$ - the recommended size for extraction of barks and roots [12], indicating that the selected method was suitable for cut raw material. According to the Brazilian Pharmacopoeia [11], the powder was classified as a coarse powder, i.e. $100 \%$ of the particles are smaller than $1.7 \mathrm{~mm}$ and no more than $40 \%$ are smaller than $355 \mu \mathrm{m}$.
The raw material shown moisture content of 7.82 $\pm 0.40 \%$, within the permitted values of $8-14 \%$ [13], suggesting that the drying time was adequate. In total ash and acid-insoluble ash determination, values of $7.95 \pm 0.12 \%$ and 0.09 $\pm 0.08 \%$ were found for $R$. ferruginea bark.

\section{Optimization of extraction process}

The yield of extractive solutions ranged from 49 to $84 \%$ (Table 3 ). The medium dry residue obtained from the solutions was $1.25 \%$ and the factor that most influenced the results was the particle size $(p<0.005)$. The influence of alcoholic degree and extraction time was not significant (Table 3 ). It was observed that both factor C (particle size) and A (alcoholic degree) had significant negative effect on the dry residue, such that when these factors change from the lower level to the upper level, the dry residue was decreased by about $3.7 \%$ and $2.6 \%$, respectively.

The $\mathrm{pH}$ value of extracts was of 5.43 to 5.84 (Table 3 ). This solution property did not show significant change $(p>0.05)$ under the influence of factors analyzed.

Table 2: Yield (\%), $\mathrm{pH}$, dry residue (\%) and MAB content $(\mathrm{mg} / \mathrm{g})$ obtained for extracts of $R$. ferruginea prepared by the method of dynamic maceration

\begin{tabular}{|c|c|c|c|c|}
\hline Batch & Yield (\%) & $\begin{array}{l}\mathrm{pH} \\
\text { (mean } \pm \mathrm{SD})\end{array}$ & $\begin{array}{l}\text { Dry residue } \\
(\% \pm \text { SD) }\end{array}$ & $\begin{array}{l}M^{\prime} B^{*} \\
(\mathrm{mg} / \mathrm{g} \pm \mathrm{SD})\end{array}$ \\
\hline 01 & 66 & $5.49 \pm 0.015$ & $1.65 \pm 0.013$ & $33.28 \pm 0.062^{\circ}$ \\
\hline 02 & 72 & $5.58 \pm 0.012$ & $1.27 \pm 0.019$ & $41.23 \pm 0.049^{m}$ \\
\hline 03 & 61 & $5.81 \pm 0.006$ & $0.98 \pm 0.032$ & $32.83 \pm 0.042^{p}$ \\
\hline 04 & 49 & $5.45 \pm 0.010$ & $2.17 \pm 0.021$ & $10.18 \pm 0.039^{s}$ \\
\hline 05 & 60 & $5.59 \pm 0.006$ & $1.35 \pm 0.028$ & $47.61 \pm 0.077$ \\
\hline 06 & 80 & $5.63 \pm 0.006$ & $1.19 \pm 0.015$ & $41.81 \pm 0.056^{m}$ \\
\hline 07 & 75 & $5.69 \pm 0.006$ & $1.62 \pm 0.013$ & $41.40 \pm 0.049^{m}$ \\
\hline 08 & 67 & $5.53 \pm 0.010$ & $1.45 \pm 0.003$ & $42.49 \pm 0.054^{\mathrm{m}}$ \\
\hline 09 & 75 & $5.52 \pm 0.006$ & $1.20 \pm 0.005$ & $37.47 \pm 0.072^{n}$ \\
\hline 10 & 79 & $5.80 \pm 0.058$ & $0.82 \pm 0.003$ & $80.83 \pm 0.124^{d}$ \\
\hline 11 & 60 & $5.65 \pm 0.006$ & $1.31 \pm 0.020$ & $55.73 \pm 0.072^{j}$ \\
\hline 12 & 61 & $5.56 \pm 0.006$ & $0.97 \pm 0.026$ & $54.68 \pm 0.136^{k}$ \\
\hline 13 & 71 & $5.63 \pm 0.006$ & $1.44 \pm 0.014$ & $49.08 \pm 0.388$ \\
\hline 14 & 82 & $5.52 \pm 0.006$ & $0.79 \pm 0.005$ & $88.34 \pm 0.249^{b}$ \\
\hline 15 & 80 & $5.84 \pm 0.006$ & $0.45 \pm 0.036$ & $103.93 \pm 0.164^{a}$ \\
\hline 16 & 66 & $5.64 \pm 0.006$ & $1.09 \pm 0.009$ & $59.01 \pm 0.097^{i}$ \\
\hline 17 & 66 & $5.63 \pm 0.006$ & $0.77 \pm 0.023$ & $83.67 \pm 0.340^{c}$ \\
\hline 18 & 60 & $5.54 \pm 0.012$ & $1.10 \pm 0.012$ & $48.43 \pm 0.219$ \\
\hline 19 & 57 & $5.38 \pm 0.012$ & $1.46 \pm 0.049$ & $56.27 \pm 0.152^{j}$ \\
\hline 20 & 50 & $5.46 \pm 0.012$ & $1.12 \pm 0.020$ & $75.99 \pm 0.218^{f}$ \\
\hline 21 & 59 & $5.49 \pm 0.012$ & $0.70 \pm 0.037$ & $79.48 \pm 0.035^{\mathrm{e}}$ \\
\hline 22 & 69 & $5.43 \pm 0012$ & $2.61 \pm 0.014$ & $27.81 \pm 0.480^{r}$ \\
\hline 23 & 81 & $5.45 \pm 0.015$ & $2.23 \pm 0.066$ & $30.90 \pm 0.074^{q}$ \\
\hline 24 & 84 & $5.49 \pm 0.006$ & $0.67 \pm 0.018$ & $79.12 \pm 0.333^{\mathrm{e}}$ \\
\hline 25 & 72 & $5.68 \pm 0.012$ & $1.48 \pm 0.003$ & $47.77 \pm 0.012$ \\
\hline 26 & 69 & $5.52 \pm 0.012$ & $1.12 \pm 0.007$ & $64.05 \pm 0.157^{g}$ \\
\hline 27 & 80 & $5.51 \pm 0.012$ & $0.79 \pm 0.008$ & $60.95 \pm 0.118^{h}$ \\
\hline
\end{tabular}


Table 3: ANOVA and regression coefficients of the polynomial model for the response variables

\begin{tabular}{|c|c|c|c|c|c|c|c|c|c|c|c|c|c|}
\hline & \multicolumn{3}{|c|}{ MAB } & \multicolumn{4}{|c|}{$\mathrm{pH}$} & \multicolumn{6}{|c|}{ Dry residue } \\
\hline & DF & $\begin{array}{l}\frac{ \pm}{0} \\
\frac{0}{0} \\
\frac{0}{ \pm 0} \\
0 \\
0\end{array}$ & 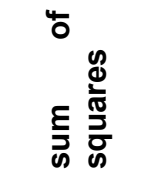 & 山 & $\begin{array}{l}\frac{0}{2} \\
\frac{0}{\pi} \\
\frac{1}{2}\end{array}$ & 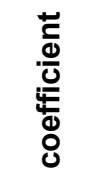 & ¿ & ᄂ & 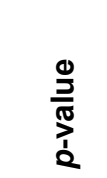 & $\begin{array}{l}\frac{+}{0} \\
\frac{0}{U} \\
\frac{4}{0} \\
0 \\
0\end{array}$ & 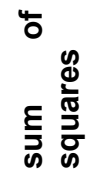 & ш & $\begin{array}{l}\frac{0}{J} \\
\frac{1}{N} \\
\text { 之̇ }\end{array}$ \\
\hline \multicolumn{14}{|l|}{ Linear } \\
\hline$b_{1}$ & 1 & 11.34 & 2272.85 & 12.927 & 0.007 & 0.10 & 0.05 & 3.764 & 0.419 & -0.05 & 0.05 & 0.774 & 0.404 \\
\hline$b_{2}$ & 1 & -1.37 & 983.48 & 0.190 & 0.675 & -0.63 & 0.00 & 0.018 & 0.501 & 0.02 & 0.01 & 0.125 & 0.732 \\
\hline$b_{3}$ & 1 & 7.39 & 33.34 & 5.594 & 0.046 & 8.47 & 0.00 & 0.175 & 0.510 & -0.35 & 2.20 & 36.861 & 0.000 \\
\hline \multicolumn{14}{|l|}{ Quadratic } \\
\hline$b_{1}$ & 1 & 10.66 & 2675.94 & 15.219 & 0.005 & 0.00 & 0.06 & 4.763 & 0.403 & -0.19 & 0.88 & 14.714 & 0.005 \\
\hline$b_{2}$ & 1 & 0.24 & 1.38 & 0.008 & 0.932 & 0.07 & 0.00 & 0.075 & 0.400 & 0.11 & 0.29 & 4.862 & 0.058 \\
\hline$b_{3}$ & 1 & 4.45 & 457.35 & 2.601 & 0.145 & -5.48 & 0.01 & 0.602 & 0.578 & -0.05 & 0.05 & 0.832 & 0.388 \\
\hline \multicolumn{14}{|c|}{ Interaction } \\
\hline$b_{12}$ & 1 & -4.41 & 233.87 & 1.330 & 0.282 & 0.02 & 0.02 & 1.779 & 0.570 & -0.02 & 0.01 & 0.094 & 0.766 \\
\hline$b_{13}$ & 1 & 5.04 & 304.62 & 1.733 & 0.225 & -0.26 & 0.01 & 0.716 & 0.498 & -0.11 & 0.15 & 2.435 & 0.157 \\
\hline$b_{23}$ & 1 & 0.17 & 0.35 & 0.002 & 0.966 & 0.13 & 0.03 & 2.611 & 0.871 & 0.02 & 0.00 & 0.045 & 0.834 \\
\hline Residual & & & 175.82 & & & & 0.01 & & & & 0.06 & & \\
\hline$F$ & & & & 2.382 & & & & 1.155 & & & & 2.886 & \\
\hline Error & 8 & & 1406.59 & & & & 0.10 & & & & 0.48 & & \\
\hline Total & 26 & & 12237.39 & & & & 0.36 & & & & 6.49 & & \\
\hline$r^{2}$ & & 0.885 & & & & 0.720 & & & & 0.926 & & & \\
\hline Adj $-R^{2}$ & & 0.626 & & & & 0.090 & & & & 0.761 & & & \\
\hline
\end{tabular}

1 = factor $A$ (alcoholic degree); 2 = factor $B$ (time of extraction); 3 = factor $C$ (particle size)
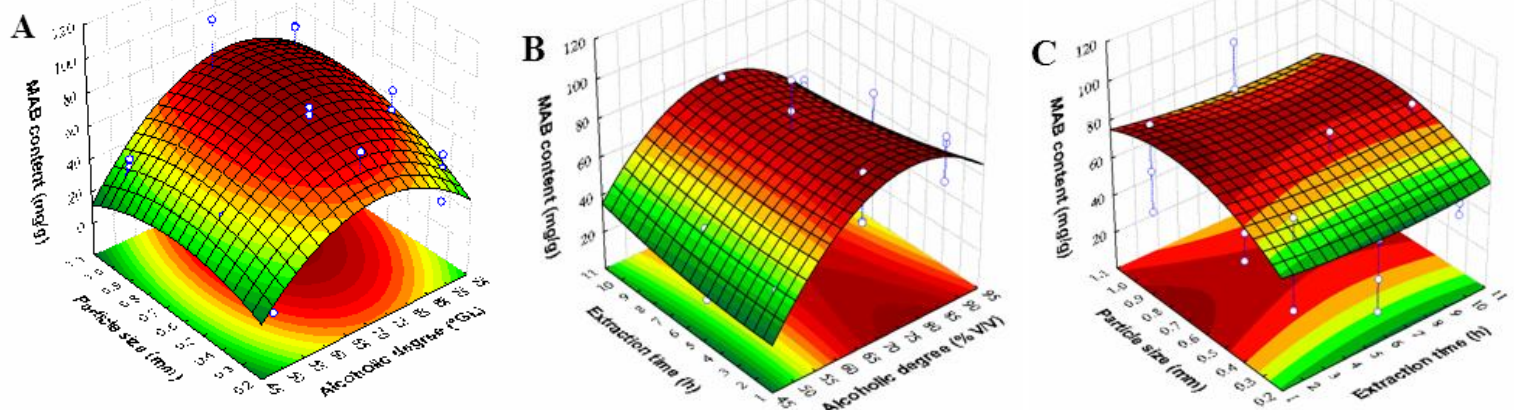

Figure 1: A - Surface response plot of $M A B$ content $(\mathrm{mg} / \mathrm{g})$ as a function of particle size $(\mathrm{mm})$ and alcoholic degree $(\% \mathrm{v} / \mathrm{v})$. B - Surface response plot of MAB content $(\mathrm{mg} / \mathrm{g})$ as a function of extraction time $(\mathrm{h})$ and alcoholic degree $(\% \mathrm{v} / \mathrm{v})$. C - Surface response plot of MAB content $(\mathrm{mg} / \mathrm{g})$ as a function of particle size $(\mathrm{mm})$ and extraction time $(\mathrm{h})$

Regarding the content of MAB, factor B was not significant, presenting $p$ values of 0.675 . Factors $A$ and $C$ presented a significant influence $(p<$ 0.05). The changing the alcoholic degree from the lower to the upper level, the MAB concentration increased by about $2.3 \%$. The influence of independent variables on the MAB content was also analyzed, using response surface analysis (Figure 1). The analysis confirmed the strong influence of the alcoholic degree on the marker extraction. $70 \%$ (v/v) hydroalcoholic solutions led to higher levels of MAB extraction. The extraction time presented less influence on the process than particle size of the herbal drug. The correlation coefficient was higher for dry residue then the MAB content and $\mathrm{pH}$. The analysis of interactions between factors 
showed no significance in all three dependent variables (dry residue, $\mathrm{pH}$ and MAB content).

Figure 2 shows the correlation between dry residue and $M A B$ content of the extraction solutions. As shown in Table 2, the batches that had lower levels of MAB also had higher dry residue contents, confirming that higher residue concentrations do not necessarily have higher marker concentrations. The correlation coefficient value was -0.8046 , i.e. the data showed a high negative correlation between these dependent variables.

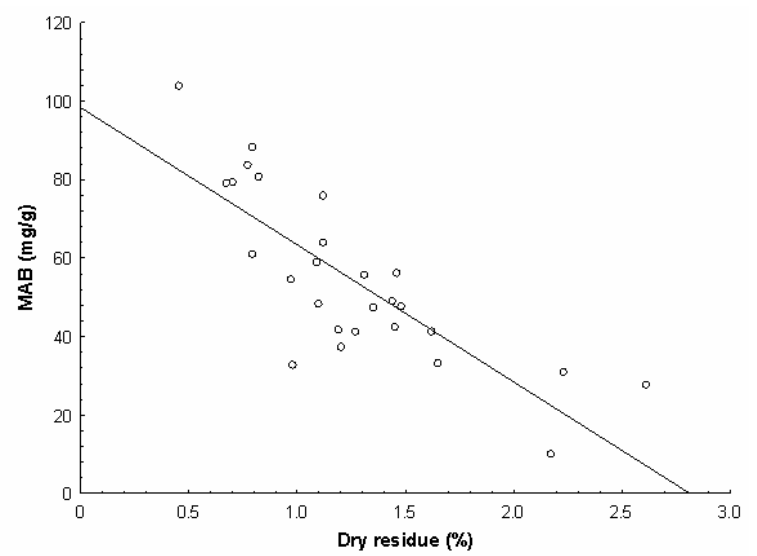

Figure 2: Plot of correlation analysis between dry residue $(\%)$ and $M A B$ content $(\mathrm{mg} / \mathrm{g})$ of the extraction solutions of $R$. ferruginea

\section{DISCUSSION}

In the development of new herbal medicines for production on an industrial scale, it is necessary to ensure a good supply of raw plant material, through optimized cultivation conditions and plant management. The three main factors that affect the quality, yield (amount of active ingredient) and productivity (amount of plant material grown) of medicinal plants are: the genetic, ontogenetic and the environment [14].

For each herbal drug, the reference values for purity tests are different. This is important in the case of $R$. ferruginea stem bark, since there is no specific monograph that determines these values for subsequent application in the herbal drug quality control routine. Thus, the moisture content, total ash and acid-insoluble ash values found can be used to establish chemical criteria for routine quality control of this species.

The Brazilian Pharmacopoeia [11] describes monographs about the plant in which the stem bark is used as herbal drug. For Rhamnus purshiana (cascara) the limits are $12 \%$ moisture content, $6 \%$ total ash and $1 \%$ acid-insoluble ash [15], for Cinnamomum verum (Ceylon cinnamon) the limits are $9 \%$ moisture content and $5 \%$ total ash; no values are given for acid-insoluble ash [13]. In studies with stem bark of Stryphnodendron adstringens (barbatiman), limits for total ash content of $1.64 \%$ and moisture content of $10.24 \%$ were found [16].

For the phytochemical and biological studies of herbal drug, extracts were obtained by maceration for 7 days, with and $90 \%$ ethanol $(\mathrm{v} / \mathrm{v})$ as solvent. For the development of standardized extracts to incorporate in dosage forms and scale up of product was necessary to optimize the extraction process. The experiments were designed using $3^{3}$ factorial design. Alcohol concentration $(A)$, extraction time $(B)$ and particle size $(\mathrm{C})$ were the independent variables and $\mathrm{pH}$, dry residue and market content were the dependent variables.

Adequate particle size definition is very important for the extraction process. The choice of grinding method and the material to be ground are parameters that must be considered in order to maximize the efficiency of the extraction process. Very fine powders can hinder certain processes, such as percolation and maceration, resulting in increased particle size and the formation of preferential channels, which requires additional filtration under pressure, and many particles are only separated by decantation process [14]. Larger fragments, however, can hinder the solvent penetration, slowing down the extraction process. The most important aspect is uniformity of particle size, which is achieved by the sieving process [17].

ANOVA showed that the alcoholic degree of the solvent was the most influential factor in the process of obtaining extraction solutions, followed by particle size of the herbal drug, and extraction time.

The higher MAB content was obtained with the use of particle size of 0.5 and $1.0 \mathrm{~mm}$, alcoholic degree of $70 \%(\mathrm{v} / \mathrm{v})$ and an extraction time of 6 $\mathrm{h}$. The fractionation of the raw material is a very important procedure during the standardization of the extraction process but on this case, the results show that there is no need to fractionate the particle size, since this parameter did not show a significant influence on marked content $(M A B)$. Although the higher MAB content was obtained with de conditions cited above, the best methodology for extractive solution obtaining was alcoholic degree of $90 \%(\mathrm{v} / \mathrm{v})$ and an extraction 
time of $2 \mathrm{~h}$ because it resulted in higher dry residue. Considering the average of particle size $(0.5 \mathrm{~mm})$, the extraction with alcohol $70 \%(\mathrm{v} / \mathrm{v})$ for $6 \mathrm{~h}$ resulted in $69.79 \mathrm{mg} / 100 \mathrm{~mL}$ of extract, and the extraction with alcohol $90 \%(\mathrm{v} / \mathrm{v})$ for $2 \mathrm{~h}$ resulted in $85.11 \mathrm{mg} / 100 \mathrm{~mL}$ of extract.

\section{CONCLUSION}

In the extraction process of stem bark of $R$. ferruginea by dynamic maceration, alcohol concentration is the most influential factor, followed by particle size of the herbal drug, and extraction time. The results show that analysis of marker content and yield of dry mass is important in establishing extraction parameters. Thus, the findings of this study indicate the best conditions for obtaining the standardized extract of $R$. ferruginea by the extraction method used. This is a significant contribution to the development of a new phytopharmaceutical intermediate product from this herbal drug.

\section{ACKNOWLEDGEMENT}

This study was supported by government grants from the Conselho Nacional de Desenvolvimento Científico e Tecnológico (CNPq) and Fundação de Amparo à Pesquisa e Inovação do Estado de Santa Catarina (FAPESC). Universidade do Vale de Itajaí (UNIVALI) also provided financial support (fellowship).

\section{REFERENCES}

1. Cragg GM, Newman DJ. Biodiversidade: um componente essencial na descoberta de fármacos. In: Yunes RA, Cechinel-Filho $V$, editors. Química de produtos naturais, novos fármacos e a moderna farmacognosia. Itajaí: Univali 2009; pp 51-81.

2. Toledo ACO, Hirata LL, Buffon MCM, Miguel MD, Miguel OG. Fitoterápicos: uma abordagem farmacotécnica. Rev Lecta 2003; 21: 7-13.

3. Hostettmann K, Queiroz EF, Vieira PC. Princípios ativos de plantas superiores. São Carlos: Edufscar 2003; $152 p$.

4. Spathelf $P$, Berger $R$, Vaccaro $S$, Tonini $H$, Borsoi GA. Crescimento de espécies nativas de uma floresta estacional decidual/ombrófila mista do Rio Grande do Sul. Ciên Florestal 2001; 11: 103-119.
5. Lorenzi H. Árvores brasileiras: manual de identificação e cultivo de plantas arbóreas do Brasil. São Paulo: Instituto Plantarum de Estudos da Flora 1998; 384 p.

6. Barretta C. Atividade antioxidante de extratos e compostos isolados de Eugenia umbelliflora e Rapanea ferruginea [dissertation]. [Itajaí]: Universidade do Vale do Itajaí 2011; Sept. p 103.

7. Baccarin T, Muceneeki RS, Bresolin TM, Yunes RA, Malheiros A, Lucinda-Silva RM. Development and validation of an HPLC-PDA method for the determination of myrsinoic acid $B$ in the extracts of Rapanea ferruginea Mez. Talanta 2011; 85: 12211224.

8. Hess S, Padoani C, Scorteganha LC, Holzmann I, Malheiros A, Yunes RA, Delle Monache F, de Souza MM. Assessment of mechanisms involved in antinociception caused by myrsinoic acid B. Biol Pharm Bull 2010; 33: 209-215.

9. Antonialli C, Silva GF, Rocha LW, Monteiro ER, Souza MM, Malheiros A, Yunes RA, Quintão NLM. Antihyperalgesic effects of myrsinoic acid $B$ in painlike behavior induced by inflammatory and neuropathic pain models in mice. Anesth Analg 2012; 115: 461-469.

10. Allen Jr LV, Popovich NG, Ansel HC. Ansel's pharmaceutical dosage forms and drug delivery systems. 9th edn. New York: Lippincott Willians \& Willians 2010; $p 710$.

11. Brasil. Farmacopéia Brasileira. 5th edn. Brasilia 2010.

12. Sonaglio D, Ortega JG, Petrovick PR, Bassani VL. Desenvolvimento tecnológico e produção de fitoterápicos. In: Simões CMO, Schenkel EP, Gosmann G, Mello JCP, Mentz LA, Petrovick PR, editors. Farmacognosia: da planta ao medicamento. 6 edn. Porto Alegre/Florianópolis: UFRGS/UFSC 2007; pp 289-326.

13. Brasil. Farmacopéia Brasileira. 4 edn. São Paulo: Atheneu 2000.

14. Sharapin N. Fundamentos de tecnologia de produtos fitoterápicos. Santafé de Bogotá: QuebecorImpreandes 2000; $p 190$.

15. Brasil. Farmacopéia Brasileira. 4 edn. São Paulo: Atheneu 1996; p 120.

16. Ardisson L, Godoy JS, Ferreira LA, Stehmann JR, Brandão MGL. Preparação e caracterização de extratos glicólicos enriquecidos em taninos a partir das cascas de Stryphnodendron adstringens (Mart.) Coville (Barbatimão). Rev Bras Farmacog 2002; 12: 27-34.

17. Marques LC, Vigo CLS. Preparação e padronização de extratos vegetais. In: Leite JPV, editors. Fitoterapia: bases científicas e tecnológicas. São Paulo: Atheneu 2009; pp 169-204. 